\title{
Assessing Waste Taxation: an Empirical Study in a Cge Multi-Pollutant Framework
}

\author{
Jaume Freire-González ${ }^{1}$ \\ Veronica Martinez-Sanchez \\ Ignasi Puig-Ventosa
}

ENT Environment and Management, Llanza, 1-7, 2 3, 08800 Vilanova i la Geltrú, Barcelona.

\begin{abstract}
Economic theory states that incineration and landfill taxes can be a good policy to reduce environmental impacts of these activities by reducing their importance and associated pollutants, while stimulating reuse and recycling of materials. In this research we assess the economic and environmental effects of these taxes in Spain with the use of a detailed dynamic CGE model, under different scenarios. We focus the economic impact on GDP and sectorial production, and the environmental impact on different impact categories: global warming potential, marine eutrophication potential, photochemical ozone formation potential, particulate matter, human toxicity (cancer and non-cancer), ecotoxicity, and depletion of fossil resources). We find in all scenarios that these taxes have a limited economic impact, while reduce all of the environmental impact categories analyzed.
\end{abstract}

\section{Keywords}

Environmental taxes, computable general equilibrium, environmental impacts, waste.

\footnotetext{
${ }^{1}$ Corresponding author.

E-mail address: jfreire@ent.cat.
} 


\section{Introduction}

Environmental taxation is a powerful tool to reduce environmental pressures (Pigou, 1920; Baumol, 1972; Baumol and Oates, 1971, 1988; European Environment Agency, 2013). There are many theoretical and empirical studies that show the environmental benefits of using taxes. However, the net effect of these taxes is not clear. The balance between reducing environmental loads (welfare increase) and increasing fiscal pressure put onto economic agents (possible welfare reduction) needs to be analyzed. There is some literature that states that depending on the design of environmental taxation, a double dividend can be obtained, i.e. a benefit in both, the environment and the economy (Freire-González, 2018). Particularly, by using government revenues to reduce other pre-existing taxes, costs of imposing an environmental tax are reduced, and in some cases, it leads to the mentioned double dividend.

The use of environmental taxation for waste policy is widely spread, particularly in Europe (Watkins et al., 2012; Fischer et al., 2012). Most common forms are municipal waste charges for collection and treatment of waste; taxes on certain products (e.g. plastic bags) and taxes on landfill and incineration. The former is usually set to cover the costs of collecting waste in municipalities or other administrative regions, but it has been changing its design in many places in order to stimulate waste reduction and source separation, with the adoption of payas-you-throw schemes (Puig Ventosa et al., 2013; Palatnik, 2014; ACR+, 2016). On the other side, taxes on certain products and taxes on landfill and incineration, are purely conceived to create incentives towards reducing and recycling waste. There are no many studies that assess the economic and environmental impacts of incineration and landfill taxes using general equilibrium methodologies. This is due to the high detail needed in the description of the economic sectors. However, some studies have tried to assess the effectiveness and/or the economic impacts of these taxes using other methods. A review of empirical evidence from different countries can be found in Bartelings et al. (2005). These authors evaluate the effectiveness of the landfill tax in the Netherlands using a computable general equilibrium (CGE) model.

This study is focused on landfill and incineration taxes. We use a dynamic CGE model with energy and environmental extensions, calibrated for the Spanish economy, to assess the economic and the environmental impacts of these taxes. From the macroeconomic impacts side, we observe the effects on GDP, on prices, and on the production of different waste treatment technologies, as well as on the rest of the economic sectors. From the environmental side we observe the effects of these taxes on 31 different pollutant emissions and on eight environmental impact categories. We set five different scenarios. The first one assesses the impacts of the current situation in Spain, the other are four fiscal proposals, of 
easy implementation in Spain that could improve the incentives towards waste reduction. Two of them also include subsides to recycling industries.

Section 2 describes the particularities of landfill and incineration taxes in Spain. Section 3 shows the data used; section 4 describes the methodology, with a description of the energyenvironment-economy model, and the different scenarios. Section 5 shows the main results and a discussion of the simulations conducted, and section 6 includes the main conclusions of the research.

\section{Taxes on landfill and incineration in Spain}

Although the national government could have promoted the adoption by the Spanish Congress of a law setting a tax on landfill and incineration, this never occurred, so these taxes are not implemented nation-wide in Spain. Regions have also the legal power to create environmental taxes in the absence of similar previous national levies. In these circumstances, several regions have created landfill and incineration taxes.

As we have calibrated our model with 2007 data (see methodology section for more details), here we analyze the state of these taxes that year to, then, set the scenarios for the analysis.

In 2007 only four regions had implemented taxes on landfill. None of them had still applied taxes on incineration:

- Catalonia: Law 16/2003, of June 13, on the financing of waste treatment infrastructures and on the tax on waste disposal (Ley 16/2003, de 13 de junio, de financiación de las infraestructuras de tratamiento de residuos y del canon sobre la disposición de residuos). This law set a fix tax rate of 10 euros/ton of municipal waste disposed of in landfills. Industrial and C\&D waste were not subject to the tax. All this remained unchanged until 2008. Puig et al. (2012) has already described this tax and discussed its effectiveness.

- Madrid: Law 6/2003, of March 20, on the tax on waste (Ley 6/2003, de 20 de marzo, del impuesto sobre residuos). This law set the following tax rates, which remained unchanged in 2007: a) 10 euros per ton of hazardous waste; b) 7 euros per ton of nonhazardous waste, excluding construction and demolition waste; and c) 3 euros per cubic meter of waste from construction and demolition. Municipal solid waste were also excluded. 
- Andalusia: Law 18/2003, of December 29, which approves fiscal and administrative measures (Ley 18/2003, de 29 de diciembre, por la que se aprueban medidas fiscales $y$ administrativas). This law approved the following tax rates, which remained unchanged in 2007: a) $35 € /$ ton of hazardous waste that is susceptible to valorization; b) $15 € /$ ton of hazardous waste that is not susceptible to valorization.

- Murcia: Law 9/2005, of December 29, on tax measures regarding assigned taxes and own taxes for 2006 (Ley 9/2005, de 29 de diciembre, de medidas tributarias en materia de tributos cedidos y tributos propios año 2006). In 2007, this law included the following tax rates: a) $15 € /$ ton for hazardous waste; b) $7 € /$ ton for non-hazardous waste; and c) $3 € /$ ton for inert waste.

\section{Data}

Data used to feed the model and create scenarios come from different sources. The model developed is calibrated with a social accounting matrix (SAM) of the Spanish economy for 2007. A SAM is a square matrix with information on the flow of payments among the various agents in the economic system that we want to represent. The SAM, which we have developed has information on commodities, industries, labor, capital, households, firms, government, high detail on taxes, investments/savings and foreign sector. The supply and use table in purchasers' prices are the core information of the SAM. In order to have homogeneous information with the rest of the sources needed to develop the SAM, we firstly based our supply and use tables on the ones from the National Statistics Institute of Spain (INE). Then we used the shares of waste treatment industries from Exiobase (Tukker et al., 2013; Wood et al., 2015) to disaggregate these industries in INE's tables. This is an important step, as we were interested in having a detailed information on different waste treatment technologies. We performed a similar process to disaggregate different energy and electricity technologies.

After adjustments, we finally obtained a SAM with 101 industries / 101 commodities, with high detail on different waste treatment technologies: (1) Incineration: food waste for treatment; paper waste for treatment; plastic waste for treatment; inert/metal waste for treatment; textiles waste for treatment; wood waste for treatment; oil/hazardous waste for treatment. (2) biogasification and land application: food waste for treatment; paper waste for treatment; sewage sludge for treatment; composting and land application; food waste for treatment. (3) Waste water treatment: food waste for treatment; other waste for treatment. (4) Landfill: food waste for treatment; paper for treatment; plastic waste for treatment; 
inert/metal/hazardous waste for treatment; textiles waste for treatment; wood waste for treatment.

Other information used to develop the SAM come from: government accounts, Social Security accounts and information on taxes have been obtained from the General Intervention Board of the State Administration (IGAE). Foreign sector accounts come from the National Statistics Institute (INE). Firms' accounts come from the Bank of Spain. Stock of capital and depreciation rates by industry come from EU KLEMS project on growth and productivity (Jäger, 2016).

Regarding the environmental information, consumption of coal, oil and natural gas, and $\mathrm{CO}_{2}$ emissions of combustion of these sources have been obtained from the IEA (2016). Moreover, from Exiobase we have obtained information on the emissions of 31 different pollutants at industry level that include: 1$)$ Greenhouse gas emissions: carbon dioxide $\left(\mathrm{CO}_{2}\right)$, methane $\left(\mathrm{CH}_{4}\right)$, nitrous oxide $\left(\mathrm{N}_{2} \mathrm{O}\right)$, sulfur hexafluoride $\left(\mathrm{SF}_{6}\right)$, hydrofluorocarbons (HFC) and perfluorocarbon (PFC), 2) General air pollutants: particulate matter < 10 microns $\left(\mathrm{PM}_{10}\right)$, sulphur dioxide $\left(\mathrm{SO}_{2}\right)$, nitrogen oxide $\left(\mathrm{NO}_{\mathrm{x}}\right)$, particulate matter $<2.5$ microns $\left(\mathrm{PM}_{2.5}\right)$, ammonia $\left(\mathrm{NH}_{3}\right)$, carbon monoxide $(\mathrm{CO})$ and total suspended particles (TSP), 3) Other organic compounds: Benzo(a)pyrene, Benzo(b)fluoranthene, Benzo(k)fluoranthene, Indeno(1,2,3-cd)pyrene, polycyclic aromatic hydrocarbons (PAH), polychlorinated biphenyl (PCBs), dioxins and furans (PCDD_F), hexachlorobenzene (HCB) and Non-methane volatile organic compounds (NMVOC) and 4) Heavy metals: arsenic (As), cadmium (Cd), chromium $(\mathrm{Cr})$, copper $(\mathrm{Cu})$, mercury $(\mathrm{Hg})$, nickel $(\mathrm{Ni})$, lead $(\mathrm{Pb})$, selenium $(\mathrm{Se})$ and zinc $(\mathrm{Zn})$.

\section{Methodology}

\subsection{The energy-environment-economy model}

We have developed a dynamic computable general equilibrium (CGE) energy-environmenteconomy model for the Spanish economy. The model is detailed in Freire-González and Ho (2018a) and in Freire-González and Ho (2018b). Although it has experienced many changes and adaptations, it is an evolved version of Jorgenson and Wilcoxen (1993); Ho and Jorgenson (2007) and Cao et al. (2013); for the analysis of environmental policies.

The model tries to represent all the agents of the economic system into four big categories: households, firms, government and foreign sector. Behavioral equations specified show how income flows across all of them in aggregate terms, so their main economic function in the model are spending money and receiving incomes. However, there are other roles assigned 
to them. Households also supply labor (which is mobile across sectors and its supply depends on the level of unemployment) and pay taxes to the government. Firms produce goods and services using capital, labor, land, energy and intermediate goods. Cobb-Douglas production functions with constant returns to scale are specified in this version of the model. Firms also pay dividends to households and taxes to the government. Government basically redistributes incomes between agents through taxes, subsidies and transfers, but they also buy goods and services and invests. The foreign sector provides goods and services through imports and buy part of the domestic goods and services produced by firms through exports. This agent also generates transfers of money (inwards and outwards) and investments from other countries. Imports are combined with the domestic output using Constant Elasticity Supply (CES) functions with an Armington assumption (Armington, 1969), thus producing a composite supply for the economy and exports are price sensitive. The current account deficit and world commodity prices are set exogenously.

They all generate savings, as the non-spent part of their incomes. These savings are important in the dynamic behavior of the model because as it is a Solow growth model, economic growth is driven by total savings. Savings from year 1 generates investments, that increase capital stock in period 2 (also decreased by depreciation rate), affecting growth possibilities. However, economic growth also depends on the rate of population growth and technical change.

There are two additional sub-models, an energy and an environmental model. The former describes the energy use through the economic system and the latter the emissions of 31 different pollutants, also detailed in Freire-González and Ho (2018a).

\subsection{Scenario development}

The study evaluates three main scenarios; however, two of them have two different configurations, so there is a total of five scenarios tested into the model.

- Scenario "current": This scenario consists in testing the economic and environmental effects of current taxes on landfill. We obtained total revenues from these taxes in 2007 and tested them into the model with the implicit effective tax rate for overall Spain obtained from the total revenues from the regions that were implementing the tax in 2007: Catalonia, Madrid, Andalusia and Murcia. As these revenues are small compared to the total government revenues in Spain, the impacts, both economic and environmental, are expected to be small. 
- Scenario 1: This scenario assumes the extension of the average tax rates to the rest of Spanish regions. The average tax rates for the different types of waste in the regions that had this tax in 2007 were approximately: municipal waste (10€/ton), industrial waste ( $7 € /$ ton for non-hazardous and $17 € /$ ton for hazardous) and construction and demolition waste $\left(3 € / \mathrm{m}^{3}\right.$ for non-dangerous and $17 € / \mathrm{m}^{3}$ for hazardous). Then, we multiply these by the amounts of each type of waste in Spain in 2007, obtained data from the national statistics institute of Spain. This results in an estimation of the total government revenues if the taxes in the current scenario were extended to all regions of Spain.

We have two sub-scenarios inside this scenario: 1a) we just test the extension of the tax; and 1b) we use the revenues of this tax to subsidize the waste recycling industries. The latter includes: "Recovered secondary raw materials"; "Food waste for treatment: biogasification and land application"; "Paper waste for treatment: biogasification and land application"; "Sewage sludge for treatment: biogasification and land application"; "Food waste for treatment: composting and land application". We subsidize these industries in relation to the share they have in value added generation.

- Scenario 2: This scenario supposes a more ambitious taxation that increases the landfill tax rates and extends the taxation to waste incineration: a) Landfill: $40 € /$ ton for municipal waste; $30 € /$ ton for non-hazardous industrial waste, and $60 € /$ ton for hazardous; and $5 € / \mathrm{m}^{3}$ for construction and demolition waste. ${ }^{2} \mathrm{~b}$ ) Incineration: $30 € /$ ton for municipal waste; 20€/ton for non-hazardous industrial waste and $40 € /$ ton for hazardous; and 10€/ton for construction and demolition waste. We have set these tax rates to simulate a scenario with more stringent policies related to waste. These type of policies could be expected considering the how far from the European targets is Spain actually performing (SWD(2017)42 final) and considering that the European Commission has explicitly recommended Spain the adoption of a landfill tax (EC, 2017). Proposed tax rates are consistent with some of the most advanced tax rates in landfill and incineration taxes in Europe.

Similarly to scenario 1 , here we have two sub-scenarios: 2a) we just test the increase of the tax rates; $2 b$ ) we use revenues of this tax to subsidize the same waste recycling industries than in scenario $1 b$.

\footnotetext{
${ }^{2}$ When C\&DW cannot be considered as inert waste due its hazardous characteristics the similar tax rate as for industrial hazardous waste is applied.
} 


\subsection{Environmental assessment}

The environmental effects of each scenario (in form of emissions or resources) have been converted into characterized environmental impact for two main reasons: first, to facilitate the interpretation of the results by grouping the emissions and resources consumption contributing to the same environmental impact category (e.g. global warming potential); and second, to compare the different elementary flows quantitatively in terms of their ability to contribute to an specific environmental impact category.

The conversion has been done by multiplying each environmental effect (amount of emission induced by each scenario) with its substance-specific characterization factor for each environmental impact category, as done in characterization step of common Life Cycle Assessment studies. The characterization factors represent the potential impact of each of single elementary flow (emission or resource) in terms of the common unit of the environmental impact category. For example, kilogram $\mathrm{CO} 2$-equivalents for greenhouse gases contributing to the impact category global warming potential.

The present study uses the ILCD recommended method 2013 (Hauschild et al., 2013) and includes the following environmental impact categories: global warming potential (GWP), marine eutrophication potential (MEP), photochemical ozone formation potential (POFP), particulate matter (PM), human toxicity (cancer, HTc, and non-cancer, HTnc), ecotoxicity (ET) and depletion of fossil resources (Df). Freshwater eutrophication and ozone depletion were excluded because the emissions reported in Exiobase dataset do not contribute to these two impact categories. Appendix 1 shows the characterization factors used in the study.

\section{Results}

\subsection{Economic impacts}

From the economic side we have obtained some results from simulations. Figure 1 shows the GDP variation of each scenario in relation to the base case. We observe in all cases that economic impacts of these taxes on the overall economic system are very low. Even in the case in which we simulate higher tax rates without using tax revenues to subsidize recycling (scenario 2a) GDP drops only by $0.045 \%$. In general, we can say that when revenues from taxation are used as a subsidy for recycling sectors (scenarios $1 b$ and 2b), GDP variation stays flat along the time, containing GDP reduction. Scenario 1b, actually tends to zero GDP variation after some years. So, it is interesting to point out that taxing landfill and incineration and at the same time subsidizing recycling industries in a revenue-neutral framework could have a very little impact in global macroeconomic indicators, like GDP. 


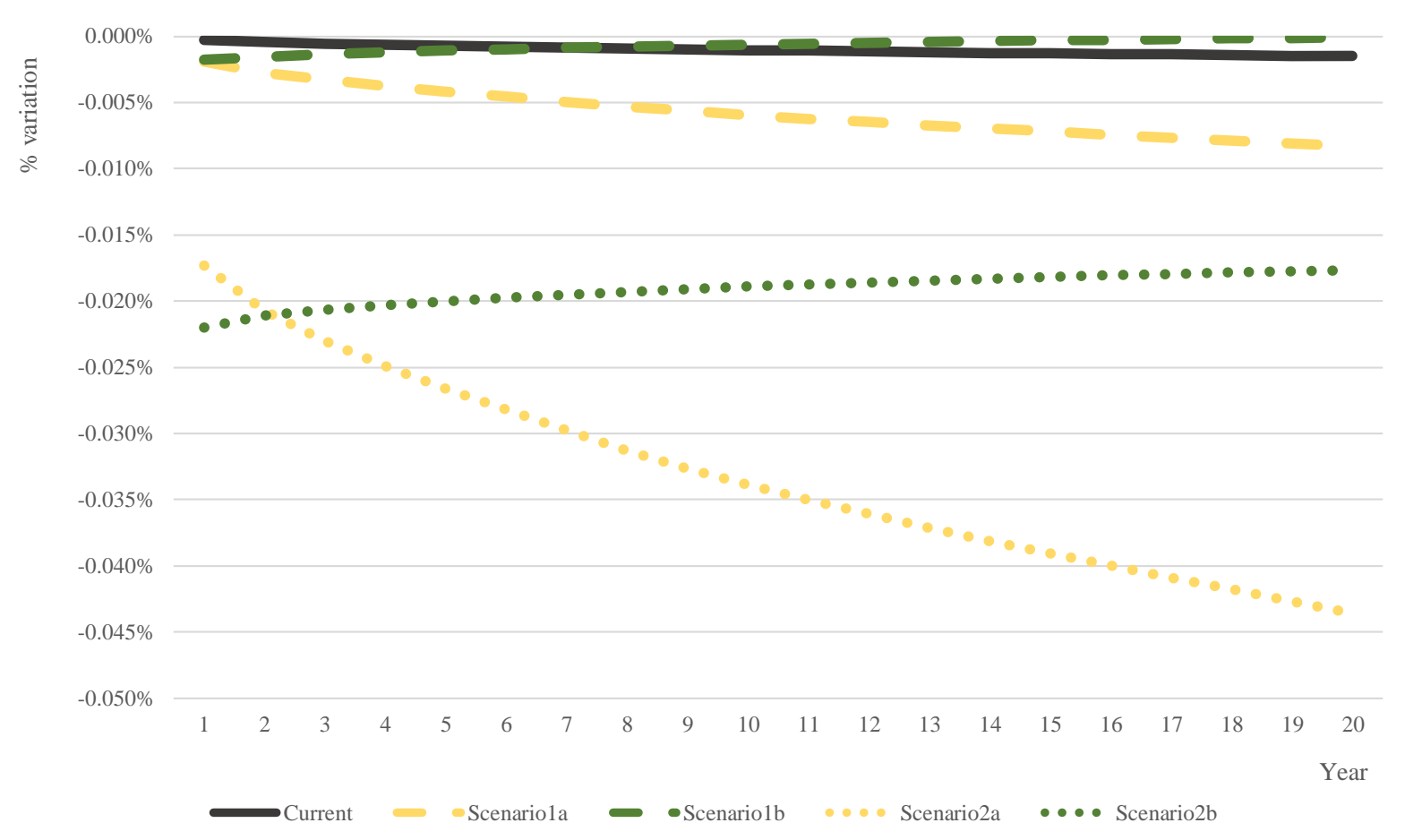

Fig. 1. GDP variation in relation to the base case in each scenario.

If we focus on economic results at industry level (in terms of production and price for year 1 and 20) we can analyze the results described in Figure 2. We observe how economic impacts are small in the current situation and mostly in landfill industries. In scenario 1a, only production of waste landfill industries goes down by $2.87 \%$ and prices go up by $2.82 \%$. There are very low effects on other industries. In scenario $1 \mathrm{~b}$, we can see how recycling industries production increase by $1.98 \%$ while prices drop by $1.84 \%$ (for year 1 ). As expected, impacts are higher in scenarios $2 \mathrm{a}$ and $2 \mathrm{~b}$, due to the general increase of tax rates. The impacts on landfill industries in scenario 2a suppose reduction on production of around $12.34 \%$, and an increase of prices of around $13.36 \%$ (for year 1). On the other side, impacts on incineration are much lower: there is a reduction of around $2.07 \%$ in production and an increase of $2.11 \%$ in prices. If we move to $2 \mathrm{~b}$, we observe similar values and also an increase of around $7 \%$ in production and a reduction of $6.16 \%$ in prices of recycling industries (for year 1 ).

In all the scenarios, even in those with higher tax rates, there are not many impacts on other sectors beyond waste treatment industries, suggesting that waste industries may not be very important in dragging other industries in the economic system. 


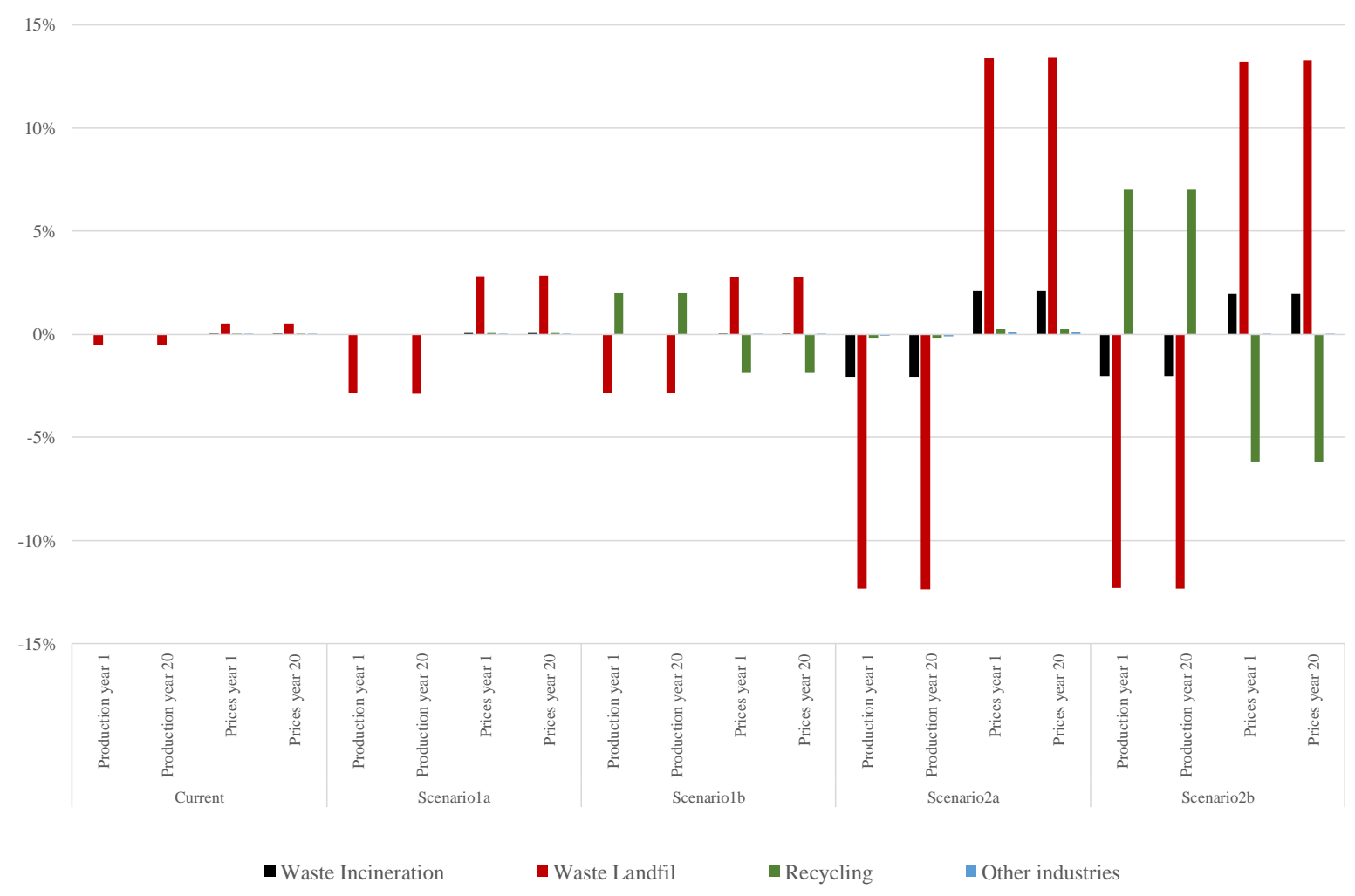

Fig. 2. Economic impacts at industry level of different waste taxation scenarios. Variations in relation to the base case.

\subsection{Energy and environmental impacts}

In this section we describe and discuss some environmental indicators from the current and the proposed tax reforms. As we showed in the methodology section, our model can track different forms of energy use through the economic system, as well as the emission of 31 different pollutants from the Exiobase project.

Figure 3 shows four energy indicators of the five scenarios. We observe a reduction in all indicators in all scenarios, so waste taxation induces energy savings and this savings are larger when for higher tax rates, i.e. savings of scenarios 2 are larger than the ones of scenarios 1. The largest variation can be observed in the indicator "electricity use", and especially in scenario $2 \mathrm{a}$, with a reduction of $0.36 \%$. The most important reductions in "electricity use" are in scenarios $1 \mathrm{a}$ and $2 \mathrm{a}$, where there are no subsidies on recycling industries. This could be explained by the fact, that at this level of taxation, the energy used for recycling activities is larger than the avoided energy related to the decrease of production 
from virgin resources and the decrease of landfill and incineration of waste. Energy intensity and $\mathrm{CO}_{2}$ intensities also go down in all scenarios, but specially in 1a and 2a, with no subsides.

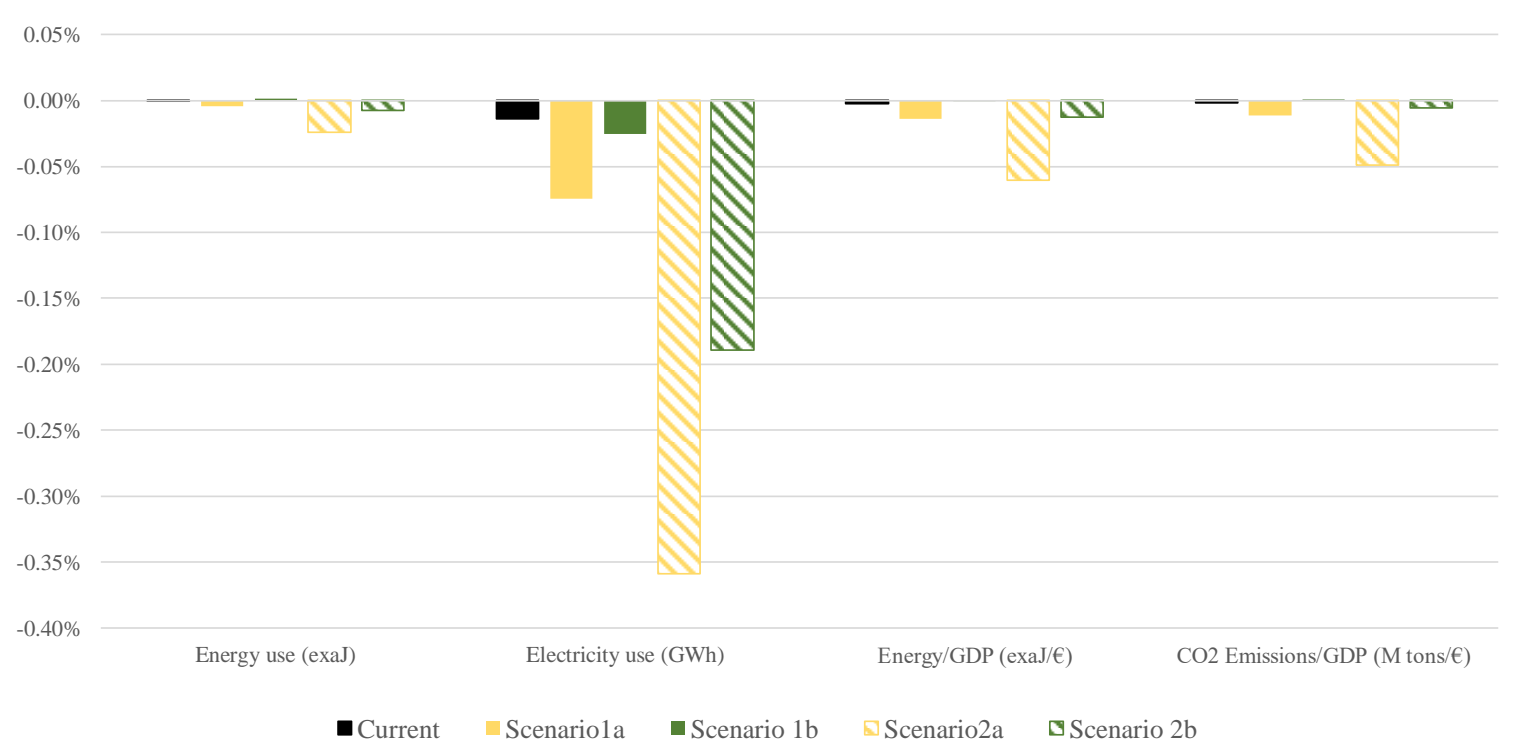

Fig. 3. Variation in different energy indicators, in relation to the base case.

Figure 4 shows the environmental results of the five scenarios included in the study as percentage of variation with respect to the characterized impact of the base case. Each graph shows the net variation as black dots, and the emission or resource contribution to such net variation in stacked-bars.

Overall, all the scenarios induce little variations in relation to the base case. The largest change was obtained by Scenario $2 b$ in the GWP category (1.7\%). This can be explained by the low magnitude of the tax revenue (in all the scenarios) compared to the global magnitude of the overall economic system. In addition, similar trends between the scenarios were observed for all the environmental impact categories, although the substances driving the changes were different for each impact category.

First, the scenario representing the current level of landfill tax in Spain (current) shows a small variation on all the impact categories. The characterized impacts are slightly lower (less than $0.07 \%$ ) than in the base case for all the impact categories, except GWP. The scenario current shows a GWP of $0.2 \%$ higher than the base case, mainly due to the increase of $\mathrm{CO}_{2}$ emissions. The latter could be explained by a diversion from landfill to incineration of some waste fractions causing fossil $\mathrm{CO}_{2}$ (e.g. plastic waste). However, it is difficult to isolate a single cause within all the macro-economic effects induced by the waste taxation.

Second, the introduction of the landfill tax in all the Spanish regions (scenario 1a) shows benefits into the environment due to the decrease of key emissions. The characterised impacts are lower than for the base case for all the impact categories, but the variations are small: 
$0.4 \%$ for GWP, $0.01 \%$ for MEP, $0.11 \%$ for POFP, $0.14 \%$ for PM, $0.23 \%$ for HTc and HTnc, $0.40 \%$ for ET and 0.01 for Df.

The substances driving such environmental benefit are different for each impact category. In the case of GWP, it is mainly due to the decrease of SF6 and PFC emissions. This decrease is also observed in the current scenario, but the benefit is hidden by the impact related to the increase of $\mathrm{CO}_{2}$ emissions. It has to be noted, however, that this large contribution of SF6 and PFC in the GWP results is not only related to the decrease of emissions (i.e. kg of SF6) but also on their high characterization factors for GWP (i.e. $22.800 \mathrm{~kg} \mathrm{CO} 2$ eq./kg SF6 and $9.160 \mathrm{~kg} \mathrm{CO} 2$ eq./kg PFC, see Appendix 1). Appendix 2 shows the direct emissions variations without the conversion to characterized impacts.

Third, the inclusion of the incineration tax in all the Spanish regions together with an increase of the landfill tax rate (scenario 2a) show also environmental benefits in all the impact categories, its characterized impacts are lower than the Baseline scenarios for all the impact categories $(0.06 \%$ for MEP, $0.53 \%$ for POFP, $0.65 \%$ for PM, $1.06 \%$ for HTc, $1.09 \%$ for HTnc, $1.90 \%$ for ET and $0.06 \%$ for Df). The emissions involved in the GHG savings are the same as for Scenario 1a, but in this case the decrease of emissions are larger than for Scenario 1a. This applied to all the impact categories, not only to GWP.

Finally, the utilization of the revenue to incentivize waste recycling activities (scenarios b) appear detrimental for the environment for all the impact categories. Their characterized impacts are larger than the impacts of scenarios a (comparing respectively $1 \mathrm{a}$ with $1 \mathrm{~b}$, and $2 \mathrm{a}$ with $2 \mathrm{~b}$ ). For example, the characterized impacts on GWP of Scenarios $1 \mathrm{~b}$ and $2 \mathrm{~b}$ are $0.2 \%$ and $1.2 \%$ larger than the baseline, respectively. This is mainly due to the increase of $\mathrm{SF} 6, \mathrm{CH}_{4}$, and PFC in both scenarios. These results highlight that, at the level of taxation simulated in scenarios $1 b$ and $2 b$, the emissions induced by increased recycling (direct emissions of remanufacture) are larger than avoided emissions related to the decrease of production from virgin resources and the decrease of landfill and incineration of waste. 

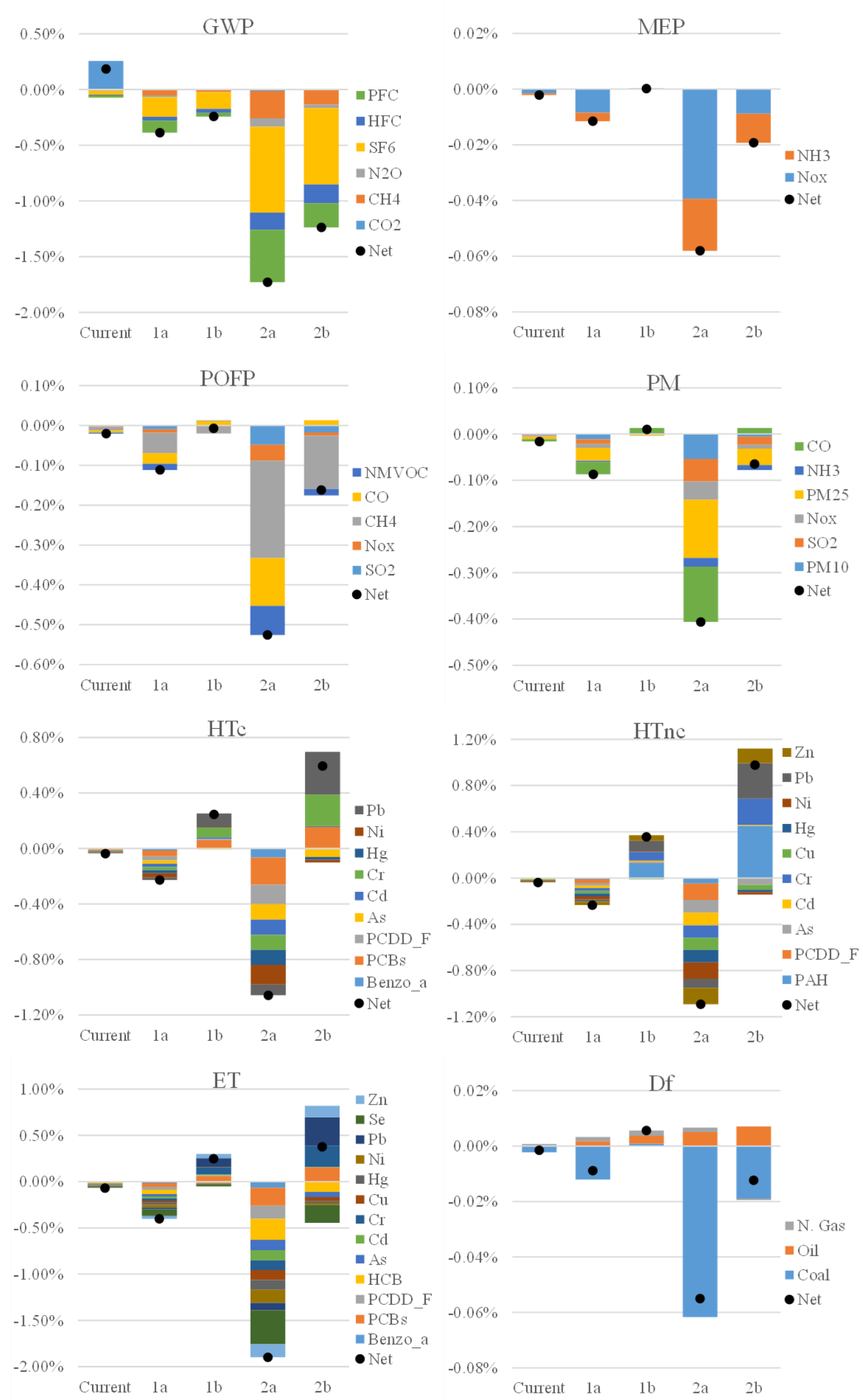

Fig. 4. Variation of environmental impacts of the 5 scenarios in relation to the base case. 


\section{Conclusions}

Environmental taxes are supposed to be good for the environment, as they reduce the importance of targeted activities, which generate environmental impacts. Most of these taxes, however, although are imposed on damaging activities were not firstly designed with this aim, but to finance the service. There is also the belief that taxes, in general, are bad for the economy, without considering or fully understanding the (economic) benefits of a better environment.

We have assessed the economic and environmental effects of incineration and landfill taxes in Spain in different scenarios. The current scenario considers the current situation, i.e. this tax is only in force in few regions. Scenario 1 one considers a "realistic" improvement in our view, as it extends this tax to the overall country. Scenario 2 is a "desirable" and more ambitious scenario that increases current tax rates, on landfill and incineration, to converge with European objectives regarding waste policies. Besides, Scenarios 1 and 2 also include two additional sub-scenarios in with we simulate a subside to recycling industries that amounts the total revenues from these taxes. These scenarios allow to depict a complete picture of the environmental and economic effects of this kind of taxes.

The results of simulations with the dynamic CGE model show in all cases very limited economic impacts, reduced when revenues are used for subsides in recycling industries. Incineration and landfill industries are always the most affected activities with low dragging effects on other industries.

On the other side, the results show some relevant benefits to the environment caused by the taxation. Although the benefit caused by the current level of taxation was small related to the overall magnitude of the economy, we can see that increases in taxation brings high benefits for all the impact categories assessed. In contrast, and unexpectedly, the use of such taxes to subsidize recycling activities decreases some of these environmental benefits to a degree that they worsen in relation to the base case. This is the case of the toxicity impact categories (HTc, HTnc and ET).

Besides the environmental impacts here included, additional aspects could be considered, which could favor the adoption of these policies. On the one hand, the impacts of landfill remain for many years after the economic activity is finalized (e.g. methane or groundwater emissions) and makes use of the land for many years, which could be consider a scarce resource close to the urban areas. On the other hand, these policies stimulate recycling whose 
main rationale is minimizing the extraction of raw materials. Recycling can be considered in practice as a sort of domestic production of raw materials, which is particularly relevant for those which are not available in the country (e.g. most metals and rare earths in the case of Spain). Recycling, thus, can also help minimizing economic vulnerability derived from excessive exposition to certain raw materials.

If we considered the non-market economic benefits (less externalities) of reducing these pollutants on aspects like human health and global warming due to landfill and incineration taxation, the negative economic impacts found could be partly or totally compensated. Further research needs to analyze this in deep.

This research shows that incineration and landfill taxes are effective in reducing environmental impacts at a low economic cost. We have considered the option of using revenues in creating subsides for recycling industries, but empirical studies have found that other uses for these revenues, like reducing other pre-existing taxes, could lead to even better results in economic terms, leading to a double dividend (Freire-González, 2018). Environmental impacts can be managed by the use of taxation. A good design of these policies is the key to obtaining good environmental results and minimize economic impacts.

\section{Acknowledgements}

This project received funding from the European Union's Horizon 2020 Research and Innovation Program under the Marie Sklodowska-Curie grant agreement, No. 654189.

\section{Author Contributions}

Jaume Freire-González designed the research, developed the CGE model, conducted tests and wrote part of the paper. Veronica Martinez-Sanchez developed the environmental impact categories analysis and wrote part of the paper. Ignasi Puig-Ventosa provided the scenarios and wrote part of the paper.

\section{Conflicts of Interest}

The authors declare no conflict of interest. 


\section{References}

ACR+ (2016). Cross-analysis of 'Pay-As-You-Throw' schemes in selected EU municipalities. Brussels, May 2016.

Armington, P.S. (1969). A theory of demand for products distinguished by place of production. Staff Papers, 16(1), 159-178.

Bartelings, H., van Beukering, P.J.H., Kuik, O.J., Linderhof, V.G.M., Oosterhuis, F.H., Brander, L.M., Wagtendonk, A.J. (2005). Effectiveness of landfill taxation. R-05/05. Institute for Environmental Studies. Vrije Universiteit.

Baumol, W. (1972). On taxation and the control of externalities. American Economic Review 62(3), 307-321.

Baumol, W., Oates, W. (1971). The use of standards and prices for the protection of the environment. Swedish Journal of Economics 73, 42-54.

Cao, J., Ho, S., Jorgenson, D.W. (2013). The economics of environmental policies in China. In: Clearer Skies over China (Nielsen, C.P., Ho, M.S., Eds.). MIT Press, Cambridge MA, pp. 329-372.

European Commission (2017). Municipal Waste Compliance Promotion Exercise. Roadmap Spain. Brussels.

European Environment Agency (2013). Green fiscal reform can create jobs and stimulate innovation across the EU, Copenhagen.

Fischer, C., Lehner, M., Lindsay Mckinnon, D. (2012). Overview of the use of landfill taxes in Europe. European Topic Centre on Sustainable Consumption and Production. ETC/SCP Working paper $1 / 2012$.

Freire-González (2018). Environmental taxation and the double dividend hypothesis in CGE modelling literature: a critical review. Journal of Policy Modeling 40(1), 194-223.

Freire-González, J., Ho, M.S. (2018a). Environmental Fiscal Reform and the Double Dividend: Evidence from a Dynamic General Equilibrium Model. Sustainability, 10(2), 501. 
Freire-González, J. Ho, M.S. (2018b). Carbon taxes and the double dividend hypothesis in a dynamic CGE framework (under review).

Hauschild, M.Z., Goedkoop, M., Guinée, J., Heijungs, R., Huijbregts, M., Jolliet, O., Margni, M., De Schryver, A., Humbert, S., Laurent, A., Sala, S., Pant, R. (2013). Identifying best existing practice for characterization modeling in life cycle impact assessment. Int. J. Life Cycle Assess. 18, 683-697.

Ho, M.S., Jorgenson, D. (2007). Policies to control air pollution damages. In: Clearing the Air: The Health and Economic Damages of Air Pollution in China (Ho, M.S., Nielsen, C.P., Eds.). MIT Press, Cambridge, MA, pp. 331-372.

Jäger, K. (2016). EU KLEMS Growth and Productivity Accounts 2016 Release, Statistical Module. Description of methodology and country notes for Spain.

Jorgenson, D.W., Wilcoxen, P.J. (1993). Reducing U.S. carbon emissions: An econometric general equilibrium assessment. Resource and Energy Economics 14, 243-268.

Palatnik, R.R., Brody, S., Ayalon, O., Shechter, M. (2014). Greening household behaviour and waste. OECD Environment Working Papers, No. 76, OECD Publishing, Paris.

Pigou, A.C. (1920). The Economics of Welfare. Macmillan and Co., Ltd, London.

Puig Ventosa, I., Calaf Forn, M., Mestre Montserrat, M. (2013). Guide for the Implementation of Pay-As-You-Throw Systems for Municipal Waste. Agència de Residus de Catalunya.

Puig Ventosa, I., González, A.C., Jofra Sora, M. (2012). Landfill and waste incineration taxes in Catalonia, Spain. In: Kreiser, L., Yábar, A., Herrera, P., Milne, J. E., Aishabor, H. (Eds.) Green Taxation and Environmental Sustainabiliy. Critical Issues in Environmental Taxation, Volume XII, p. 244-257. Edward Elgar.

SWD(2017)42 final. The EU Environmental Implementation Review: Common Challenges and how to combine efforts to deliver better results. European Commission.

Tukker, A., de Koning, A., Wood, R., Hawkins, T., Lutter, S., Acosta, J., Rueda Cantuche, J.M., Bouwmeester, M., Oosterhaven, J., Drosdowski, T., Kuenen, J. (2013). EXIOPOL development and illustrative analyses of a detailed global MR EE SUT/IOT. Economic Systems Research 25 (1), 50-70. 
Watkins, E., Hogg, D., Mitsios, A., Mudgal, S., Neubauer, A., Reisinger, H., Troeltzsch, J., Van Acoleyen, M. (2012). Use of economic instruments and waste management performances - Final Report. Study prepared for the European Commission, DG Environment.

Wood, R., Stadler, K., Bulavskaya, T., Lutter, S., Giljum, S., de Koning, A., Kuenen, J., Schütz, H., Acosta-Fernández, J., Usubiaga, A., Simas, M., Ivanova, O., Weinzettel, J., Schmidt, J.H., Merciai, S., Tukker, A. (2015). Global sustainability accounting-developing EXIOBASE for multi-regional footprint analysis. Sustainability 7(1), 138-163. 


\section{Appendix 1. Characterization factors of the different emissions and resources included in the environmental assessment}

Table 1. Characterization factors of the different emissions and resources for the different impact categories included in the environmental assessment.

\begin{tabular}{|c|c|c|c|c|c|c|c|c|}
\hline Name & $\begin{array}{c}\text { GWP } \\
\mathrm{kg} \mathrm{CO}_{2} \text { eq }\end{array}$ & $\begin{array}{c}\text { MEP } \\
\text { kg N eq. }\end{array}$ & $\begin{array}{c}\text { POCP } \\
\text { kg } \\
\text { NMVOC } \\
\text { eq. }\end{array}$ & 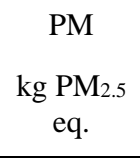 & $\begin{array}{l}\text { HTc } \\
\text { CTUh }\end{array}$ & $\begin{array}{l}\text { HTnc } \\
\text { CTUh }\end{array}$ & $\begin{array}{c}\text { ET } \\
\text { CTUe }\end{array}$ & $\begin{array}{l}\text { Df } \\
\text { MJ }\end{array}$ \\
\hline $\mathrm{CO} 2$ & 1 & & & & & & & \\
\hline PM10 & & & & 0.227 & & & & \\
\hline $\mathrm{SO} 2$ & & & 0.08 & 0.061 & & & & \\
\hline Nox & & 0.389 & 1 & 0.007 & & & & \\
\hline PM25 & & & & 1 & & & & \\
\hline $\mathrm{CH} 4$ & 25 & & 0.01 & & & & & \\
\hline $\mathrm{N} 2 \mathrm{O}$ & 298 & & & & & & & \\
\hline NH3 & & 0.092 & & 0.067 & & & & \\
\hline $\mathrm{CO}$ & & & 0.046 & 0.0003 & & & & \\
\hline $\begin{array}{l}\text { Benzo(a)pyre } \\
\text { ne }\end{array}$ & & & & & $3.6^{*} 10^{-5}$ & & 110 & \\
\hline PAH & & & & & & $2.4 * 10^{-7}$ & & \\
\hline PCBs & & & & & $9.1 * 10^{-5}$ & & 1,800 & \\
\hline PCDD_F & & & & & 14.5 & $3.6 * 10^{-6}$ & 62,000 & \\
\hline HCB & & & & & & & 620 & \\
\hline NMVOC & & & 1 & & & & & \\
\hline As & & & & & $3.3 * 10^{-4}$ & 0.017 & 17,000 & \\
\hline $\mathrm{Cd}$ & & & & & $2.2 * 10^{-4}$ & 0.045 & 3,900 & \\
\hline $\mathrm{Cr}$ & & & & & $2.2 * 10^{-3}$ & $2.1 * 10^{-4}$ & 21,000 & \\
\hline $\mathrm{Cu}$ & & & & & & $1.3 * 10^{-5}$ & 23,000 & \\
\hline $\mathrm{Hg}$ & & & & & $7.0^{*} 10^{-3}$ & 8.3E-01 & 12,000 & \\
\hline $\mathrm{Ni}$ & & & & & $5.2 * 10^{-5}$ & $2.9 * 10^{-6}$ & 6,100 & \\
\hline $\mathrm{Pb}$ & & & & & $2.7 * 10^{-5}$ & $9.4 * 10^{-3}$ & 180 & \\
\hline $\mathrm{Se}$ & & & & & & & 3,000 & \\
\hline $\mathrm{Zn}$ & & & & & & 0.016 & 17,000 & \\
\hline SF6 & 22,800 & & & & & & & \\
\hline HFC & 7,850 & & & & & & & \\
\hline PFC & 9,160 & & & & & & & \\
\hline Coal & & & & & & & & 19.1 \\
\hline Oil & & & & & & & & 42.3 \\
\hline Natural Gas & & & & & & & & 44.1 \\
\hline
\end{tabular}

Source: own elaboration. 


\section{Appendix 2. Average annual variations of individual pollutants}

Figure 5 shows the average annual variations of different pollutants modelled, under the different scenarios. Although there is a reduction of most pollutants, there are some pollutants, such as SF6, PFC, PCBs, HBC, Zn, Cr, Pb and PAH that increase in the scenarios that include subsides in recycling industries. However, we observe a general decrease in all the other pollutants in relation to the base case. The current situation shows a very slight reduction in all pollutants, meaning that current taxes might be too small to reduce pollution. Scenario 1a and especially, scenario $2 \mathrm{a}$, lead to a higher reduction in most pollutants.

Similarly to economic impacts, annual average variations are small (between $+0.4 \%$ and $0.8 \%$ ). This is due to the relative importance of industries affected by the scenarios in relation to the rest of the emissions of the economic system.

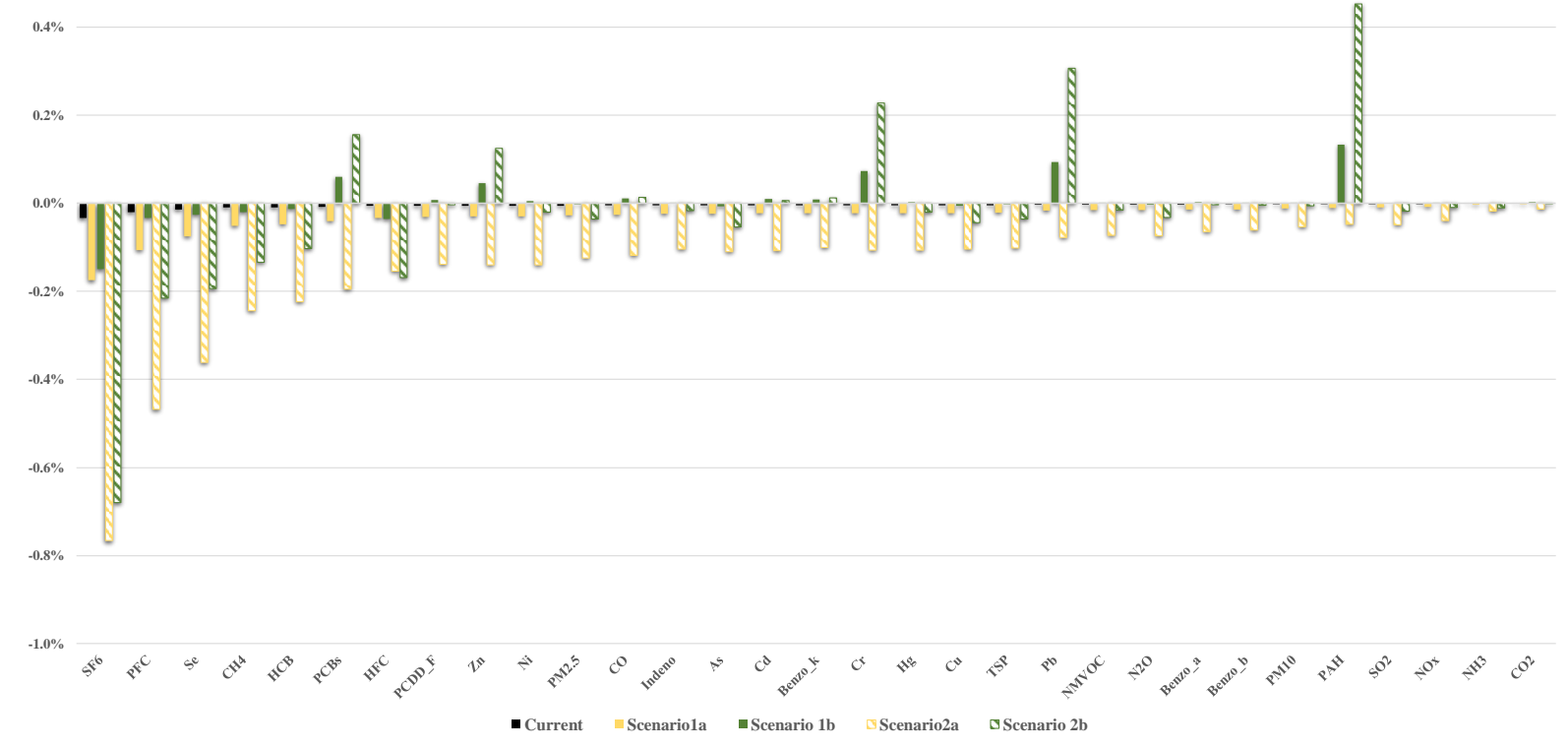

Fig. 5. Average annual variations of pollutant emissions variations in relation to the base case, under different scenarios. 